\title{
Penerapan Teknik Color Grading dan Musik Scoring Pada Tahap Paska Produksi Film Horor "Waktu Terlarang"
}

\author{
Dian Retno Ariani ${ }^{1}$, Fandy Neta, S.Pd., M.Pd.T. ${ }^{2}$ \\ Program Studi Teknik Multimedia dan Jaringan, Jurusan Teknik Informatika \\ Politeknik Negeri Batam \\ Batam, Indonesia \\ dianretnoariani111@gmail.com, fandyneta@polibatam.ac.id
}

\begin{tabular}{l} 
Article Info \\
\hline Article history: \\
Received Jun $12^{\text {th }}, 2021$ \\
Revised Jun $20^{\text {th }}, 2021$ \\
Accepted Jul $26^{\text {th }}, 2021$ \\
\hline
\end{tabular}

Keyword:

Film

Myth

Color Grading

Music Scoring

\begin{abstract}
Film is one of the modern and effective communication media as sending good information or messages, supporting interesting stories, clear sound, clear images, and high-resolution video, and the film editing process will greatly help to make films clearer in realizing the purpose of the film to be made. Its development is so fast, this happens in all aspects, both in terms of the story to its implementation. Along with the development of the current era, the film also experienced a development by having a lot of film genres circulating in the midst of the community, one of which is the genre of horror films that are lifted from a public trust that occurs in the surrounding environment, namely myths.
\end{abstract}

This final project the author makes a short film that lifts the myth of sleep deprivation at sunset and applies color grading techniques and music scoring as a solution for creating digital video quality. This issue is interesting to discuss because it will help improve and provide new colors in Indonesian cinema.

\section{PENDAHULUAN}

Era dunia digital begitu berkembangnya teknologi di bidang audio visual atau video, yang menghasilkan sebuah karya berupa Film, iklan, dokumenter dan multimedia lainnya. Saat ini film telah menjadi kebutuhan manusia akan dunia hiburan melalui sebuah media elektronik. Film juga salah satu media komunikasi modern dan efektif sebagai penyampaian informasi atau pesan yang baik dan benar, dengan didukungnya cerita yang menarik, suara yang jernih, gambar yang jelas, dan video dengan resolusi tinggi, serta proses editing film yang akan sangat membantu untuk membuat film menjadi lebih nyata dalam mewujudkan maksud dan tujuan film yang akan dibuat.[1]

Film merupakan media untuk memberikan informasi atau menyampaikan pesan yang berupa pembelajaran ataupun hiburan bagi masyarakat. Berbagai macam budaya di Indonesia dapat menjadi referensi untuk menghasilkan sebuah ide yang menarik. Seiring berkembangnya jaman topik-topik yang berbau mistis sangat mempengaruhi minat masyarakat. Pembahasan mengenai genre film yang beredar ditengah - tengah masyarakat, yaitu film mitos atau yang lebih dikenal dengan sebutan urban legend yang diangkat dari kepercayaan masyarakat yang terjadi dilingkungan sekitar, salah satunya adalah mitos larangan tidur diwaktu magrib yang telah menjadi kepercayaan sebagian masyarakat. Hal ini menjadi topik yang menarik untuk diangkat menjadi sebuah film. Film horor memiliki tujuan untuk membuat kesan atau efek rasa kaget, serta untuk menakut-nakuti penonton [9]. Meskipun film horor dapat membuat kesan menyeramkan, rasa kaget dan takut, namun film horror masih popular dan masih banyak diminati oleh masyarakat [10].

Film bergenre horor dari tahun ke tahun menjadi film yang banyak diminati masyarakat di Indonesia. Ditandai dengan film Kuntilanak pada tahun 2006 yang disutradarai Rizal Mantovani yang meraih penonton di atas 1,5 juta orang [3]. Selain itu, film bergenre horor saat ini juga mengambil cerita-cerita yang berkembang di masyarakat. Oleh karena itu, sadar akan kemampuan potensi film sebagai hiburan 
yang banyak diminati masyarakat, maka penulis memutuskan untuk membuat sebuah film pendek tentang mitos bergenre horror yang berjudul "Waktu Terlarang".

Sebuah film yang mampu memainkan emosi penonton adalah dambaan bagi pembuat film. Keberhasilan dari sebuah film juga sangat tergantung pada kualitas produksi film tersebut. Serta pentingnya tahapan paska produksi dilakukan agar film yang dihasilkan nantinya berpengaruh terhadap mood dan kepuasan penonton. Color grading dilakukan sebagai proses perbaikan atau perubahan warna, mengubah dan meningkatkan warna dari video. Penerapan color grading dapat membangun karakter dari sebuah film horor. Color grading dapat mendefinisikan warna pada setiap scene, seperti ketika ingin membangun suasana menegangkan maka warna yang digunakan adalah warna gelap. Warna merupakan kesan yang diperoleh mata terhadap benda-benda yang dipantulkan oleh cahaya. Ditinjau dari segi emosi seseorang, makna warna yang ada dapat menunjukkan kesan perasaan akan sesuatu hal. Sedangkan musik scoring juga merupakan bagian penting dalam film. Ketika musik bergabung dengan visual bergerak, atmosfer cerita semakin kuat dan membentuk banyak pengalaman bagi penontonnya.

Berdasarkan latar belakang diatas penulis akan membahas mengenai penerapan dan analisis proses color grading dan musik scoring terhadap film pendek "Waktu Terlarang", karena pewarnaan dan suara pada film sangat berpengaruh untuk menambah ketertarikan pada produksi film. Sehingga penulis tertarik untuk mengajukan ide tugas akhir yang berjudul "Penerapan Teknik Color grading dan Musik scoring Pada Tahap Paska Produksi Film Horor "Waktu Terlarang"

\section{METODE PENELITIAN}

Penelitian ini menggunakan metode pengembangan Villamil-Molina untuk membuat sebuah film pendek ber-genre horor yang berdurasi kurang lebih 10 menit. Dan juga menggunakan metode penelitian kuantitatif. Metode pengembangan ini terdiri dari 5 tahapan yaitu development, pra production, production, post production dan delivery. Jurnal ini akan menguraikan tahapan Post-Production dan Delivery yang membahas tentang penerapan teknik color grading dan musik scoring pada tahap paska produksi. Tahap perancangan model Vilamill-molina disajikan pada gambar 1.

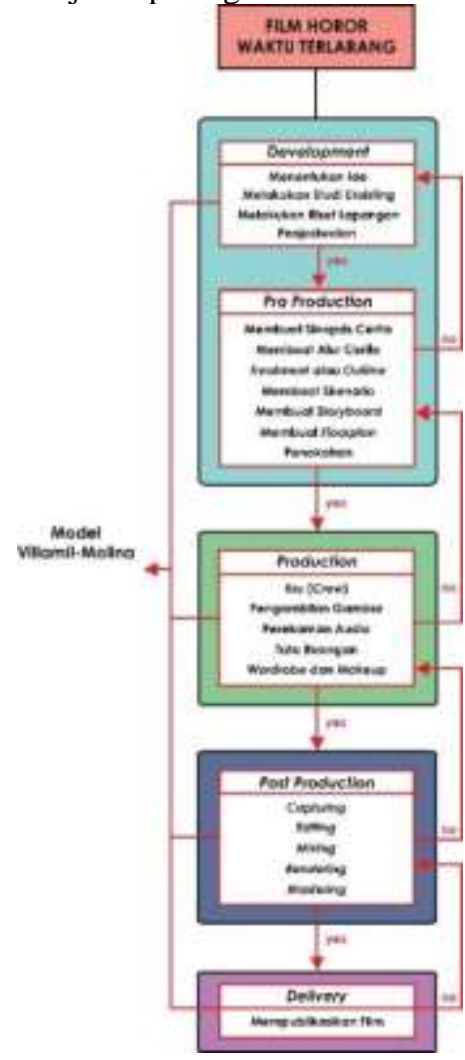

\section{A. Post Production}

Gambar 1. Tahapan Perancangan Model Vilamill Molina

Pengembangan produk multimedia pada tahap ini memasuki tahapan editing serta melakukan pengujian alfa dan beta. Tahap paska produksi adalah penyelesaian akhir dari produksi. Setelah proses pengambilan gambar selesai dilakukan, editor mulai untuk masuk ke tahap editing. Tahap ini terdapat beberapa aktivitas yang dilakukan. Tahapan- tahapan yang dilakukan disajikan pada Gambar 2. 


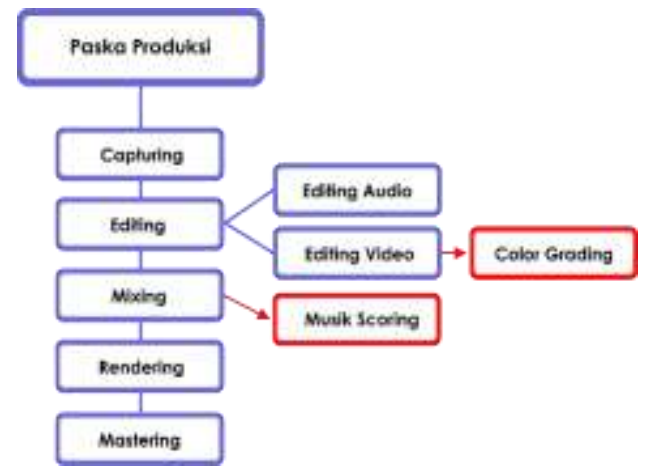

1) Capturing

Gambar 2. Tahapan Paska Produksi

Pada proses capturing dilakukan pemindahan sumber gambar dari pita video atau media penyimpanan lain ke dalam data komputer dan disimpan di ruang hardisk.

2) Editing

Tahap ini dilakukan proses editing. Dimana pada tahap editing ini dibagi menjadi 2 tahap yaitu editing audio dan editing video.

a. Editing audio

Editing audio diperlukan untuk meminimalisir kebisingan atau noise pada rekaman audio (dubbing) dari hasil alat perekam suara yang dipergunakan. Hasil rekaman audio akan di edit menggunakan aplikasi Audacity.

b. Editing video

Proses yang dilakukan antara lain drafting, hard cutting, soft cutting, linking, superimposing, dan pemberian effect. Selanjutnya pada proses editing video akan dilakukan penerapan color grading. Seperti membuat keadaan latar tempat tersebut menjadi lebih terlihat suram dan menakutkan dalam hal ini editor akan lebih dominan bermain pada warna biru kegelapan [10]. Proses ini dilakukan menggunakan lumetri color yang ada pada adobe premiere pro cc 2017.

3) Mixing

Narasi yang sudah direkam dan ilustrasi musik yang sudah direkam dimasukan kedalam pita hasil editing online sesuai dengan petunjuk atau ketentuan yang tertulis dalam naskah editing. Serta pada tahap ini dilakukan juga proses musik scoring yang nantinya akan digunakan pada film. Proses musik scoring dilakukan pada aplikasi adobe premiere pro cc 2017 dengan melakukan spotting atau penempatan musik pada tiap potongan-potongan adegan dalam film dan mengatur tinggi rendahnya volume musik. Keseimbangan antara sound effect, suara asli, suara narasi dan musik harus dibuat sedemikian rupa sehingga tidak saling mengganggu dan terdengar jelas. Suara yang menciptakan rasa takut selalu bermain dalam kontras yang mengejutkan sehingga dapat menarik penonton ke dalam suasana, dan saat itulah otak akan diisi oleh perasaan takut. Maka dari itu pentingnya memainkan volume dalam menciptakan musik horor [4].

4) Rendering

Proses berikutnya adalah rendering, dimana proses ini menggabungkan keseluruhan file-file video yang telah dirangkai sesuai dengan kebutuhan skenario menjadi satu kesatuan utuh untuk dijadikan satu format file sendiri.

\section{5) Mastering}

Proses dimana file yang telah dirender dipindahkan ke dalam media kaset, VCD, DVD atau media lainnya. Produk dipublikasi menggunakan media youtube sebagai sarana responden dalam memberikan penilaian terhadap hasil produk.

\section{B. Teknik Pengumpulan Data}

Teknik pengumpulan data yang digunakan dalam penelitian ini yaitu melalui kuesioner. Kuesioner atau angker adalah teknik pengumpulan data yang dilakukan dengan cara memberi seperangkat pertanyaan atau pernyataan tertulis kepada responden kemudian responden tersebut akan menjawabnya [11]. Responden dikelompokkan menggunakan alpha testing dan beta testing. Tahap alpha testing dilakukan pengecekan terhadap produk yang telah dirancang oleh penulis untuk ahli yang mengerti tentang film ataupun pernah membuat film sedangkan beta testing dilakukan terhadap responden yaitu masyarakat umum yang 
menyukai film bergenre horor berdasarkan indikator-indikator terkait pewarnaan dan musik yang kemudian akan dilakukan analisis dari film yang telah dibuat.

\section{Teknik Pengolahan Data}

Teknik Pengolahan data bertujuan untuk mengubah atau menyederhanakan data mentah dari hasil pengukuran menjadi data yang sistematis. Pengolahan data meliputi kegiatan:

1. Editing

Editing adalah proses memeriksa data yang telah terkumpulkan dari kuesioner, yang bertujuan untuk menghilangkan kesalahan yang terjadi pada pengumpulan data saat di lapangan.

2. Coding

Coding adalah kegiatan pemberian kode pada setiap data yang terkumpul di setiap instrument penelitian. Tujuan pengkodean ini untuk memudahkan pada analisis data terutama jika data/informasi tersebut dianalisis melalui tabel-tabel.

3. Pemberian skor atau nilai:

Penentuan skor dalam pengolahan data ini menggunakan Skala Likert. Kriteria penilaian ini digolongkan dalam lima tingkatan dengan masing-masing penilaian disaijkan dalam Tabel 1.

Tabel 1. Kriteria Penilaian

\begin{tabular}{|l|c|}
\hline Jawaban Pertanyaan & Bobot Nilai \\
\hline SS (Sangat Sesuai) & 5 \\
\hline S (Sesuai) & 4 \\
\hline KS (Kurang Sesuai) & 3 \\
\hline TS (Tidak Sesuai) & 2 \\
\hline $\begin{array}{l}\text { STS (Sangat Tidak } \\
\text { Sesuai) }\end{array}$ & 1 \\
\hline
\end{tabular}

4. Tabulasi

Tabulasi adalah pembuatan tabel yang berisi data-data yang telah diberi kode sesuai dengan analisis.

\section{Analisis Data}

Penelitian tugas akhir ini dilakukan teknik analisis yaitu dengan statistik deskriptif pada pengujian alpha dan analisis Uji T berpasangan pada pengujian beta. Statistik deskriptif digunakan untuk menganalisis data dengan cara mendekripsikan data dalam bentuk yang mudah dibaca sehingga memberikan informasi tersebut lebih lengkap dan berhubungan dengan memberikan keterangan-keterangan mengenai suatu data atau keadaan, dengan kata lain melihat gambaran secara umum dari data yang didapatkan. Data yang diperoleh akan diolah dan dianalisis dengan menggunakan metode skala likert. Tingkat persetujuan dalam kuisioner telah memenuhi kelima syarat yang dikemukakan oleh likert [11]. Maka dilakukan perhitungan terhadap hasil kuisioner dengan menggunakan rumus:

\section{Skor $=\mathbf{T} \times$ Pn}

$\mathrm{T}=$ Total responden dalam satu pertanyaan

Pn $=$ Pilihan angka skor Likert

Setelah total skor didapatkan, selanjutnya yang harus dilakukan adalah menentukan index dalam persen dengan menggunakan rumus sebagai berikut:

\section{Index $\%=\frac{\text { Total skor }}{\text { Skor yang diharapkan }} \times 100 \%$}

Hasil perhitungan index akan dievaluasi dengan nilai akhir dan dirujuk dengan interval sebagai berikut: a. Index $0 \%-19,99 \%=$ Sangat Tidak Setuju

b. Index $20 \%-39,99 \%$ = Tidak Setuju

c. Index $40 \%-59,99 \%$ = Ragu-ragu

d. Index $60 \%-79,99 \%=$ Setuju

e. Index $80 \%-100 \%$ = Sangat Setuju [2]

Serta dilakukan analisis Uji-t berpasangan pada pengujian beta. Uji-t berpasangan atau biasa yang disebut paired $t$-test merupakan salah satu metode pengujian hipotesis yang menggunakan data tidak bebas atau (berpasangan). Ciri-ciri yang paling sering ditemui pada kasus yang berpasangan adalah satu individu (objek penelitian) mendapat 2 buah perlakuan yang berbeda. Walaupun menggunakan individu yang sama, peneliti tetap memperoleh dua data sampel, dari perlakuan pertama dan kedua atau dengan kata lain data 
pada sampel kedua merupakan perubahan dari data sampel pertama [6]. Data hasil pretest (sebelum) dan posttest (sesudah) pada pengujian beta akan diuji dengan uji-t (t-test) dengan bantuan software Statistika yaitu SPSS.

Hipotesis 1

H0 : Penerapan teknik color grading tidak berpengaruh terhadap tahapan paska produksi film horor "Waktu Terlarang"

H1 : Penerapan teknik color grading berpengaruh terhadap tahapan paska produksi film horor "Waktu Terlarang"

Hipotesis 2

H0 : Penerapan musik scoring tidak berpengaruh terhadap tahapan paska produksi film horor "Waktu Terlarang"

H1 : Penerapan musik scoring berpengaruh terhadap tahapan paska produksi film horor "Waktu Terlarang" Dasar pengambilan keputusan dalam uji t paired adalah sebagai berikut:

- Jika nilai t hitung < t table atau nilai Sig. >0,05, maka Ho diterima.

- Jika nilai t hitung > t table atau nilai Sig. < 0,05, maka Ho ditolak dan H1 diterima. [7]

\section{E. Delivery}

Setelah produk selesai dianalisis. Langkah akhir yang akan dilakukan yaitu proses delivery. Pada tahap delivery ini akan dilakukan proses akhir pengemasan produk berupa video berformat MP4 dengan durasi waktu 8 menit 50 detik yang dipubikasi melalui youtube dan dikemas dalam bentuk CD/DVD untuk diserahkan kepada pihak perusahaan. Sehingga film ini dapat menjadi portofolio perusahaan untuk diikutkan festival perlombaan film nantinya. Berikut ini hasil publikasi publik film horor "Waktu Terlarang" melalui Youtube dan Genflix festival film 2020 disajikan pada gambar 3 dan 4.

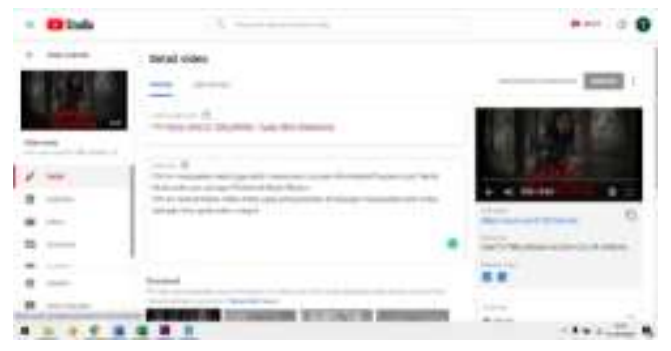

Gambar 3. Proses publikasi ke Youtube

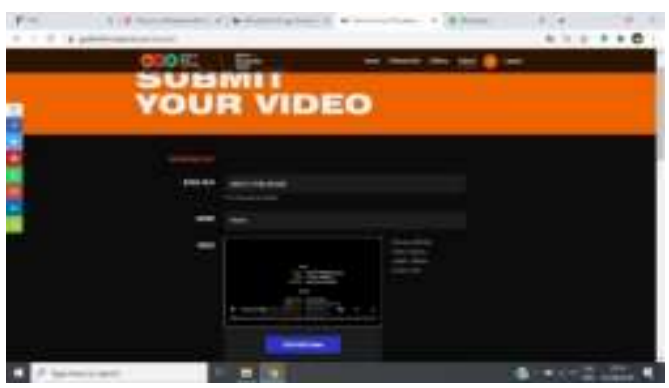

Gambar 4. Proses publikasi ke Festival Film

\section{HASIL DAN PEMBAHASAN}

\section{1) Proses Penerapan Color grading}

Setelah dilakukan proses penggabungan video, maka langkah selanjutnya menerapkan proses pewarnaan pada film atau yang biasa dikenal yaitu color grading. Proses ini dilakukan menggunakan lumetri color yang ada pada adobe premiere pro cc 2017 dengan menginput LUT preset warna dan kemudian menyesuaikan tingkat warna RGB dengan mengatur tingkat tone warna, exposure, contrast, shadows, dan saturation. Proses color grading berhubungan dengan memanajemen warna dasar yang digunakan untuk mengubah atau meningkatkan nuansa pada film. Warna dasar sebuah video tidak memiliki kecacatan, namun dengan color grading video tersebut dapat memiliki tampilan yang berbeda-beda. 
Menurut Susan Blackmore selaku psikolog sekaligus dosen di University of Plymouth, pikiran kita cenderung merasa ada kehadiran sosok lain ketika situasinya gelap, hal inilah yang digunakan dalam film horor untuk menakuti kita ketika menonton. Maka, mayoritas film horor menggunakan pewarnaan yang cenderung gelap atau mengambil latar waktu pada malam hari [5].

Konsep pewarnaan yang akan digunakan pada pembuatan film horor "Waktu Terlarang" akan dominan bermain pada nuansa gelap dengan tambahan warna kebiruan. Konsep ini pun sudah dilakukan pada beberapa film horor. Diantaranya, film The Ring (2002), menggunakan nuansa biru gelap yang hadir saat hantu wanita keluar dari sumur digunakan untuk membuat tampilan sang hantu yang serba putih jadi lebih menakutkan. Lalu, pada film Saw (2004), warna kebiruan juga selalu muncul pada adegan yang berlatar tempat di ruang penyiksaan dari Adam Stanheight dan Lawrence Gordon. Hal ini dilakukan untuk menambah suasana yang lebih suram dan menegangkan kepada penonton [5]. Proses pengerjaan color grading dilakukan selama kurang lebih 2 minggu untuk mendapatkan hasil yang diinginkan dan sesuai dengan naskah skenario yang dirancang. Proses color grading disajikan pada Gambar 5.
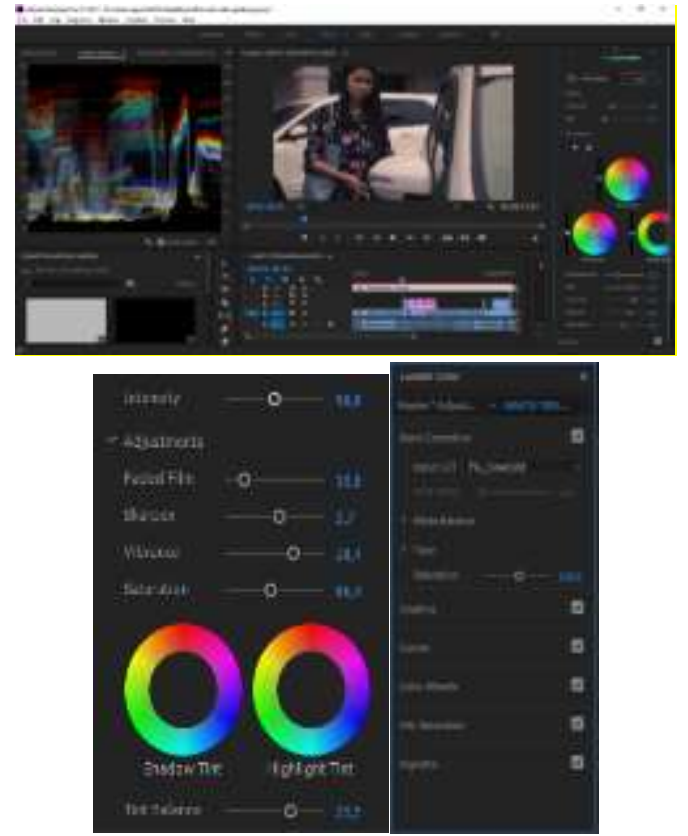

Gambar 5. Proses Color grading

\section{2) Hasil Implementasi Color grading}

Hasil implementasi dari proses color grading dapat dilihat pada tabel 2.

Tabel 2. Hasil Implementasi Color grading

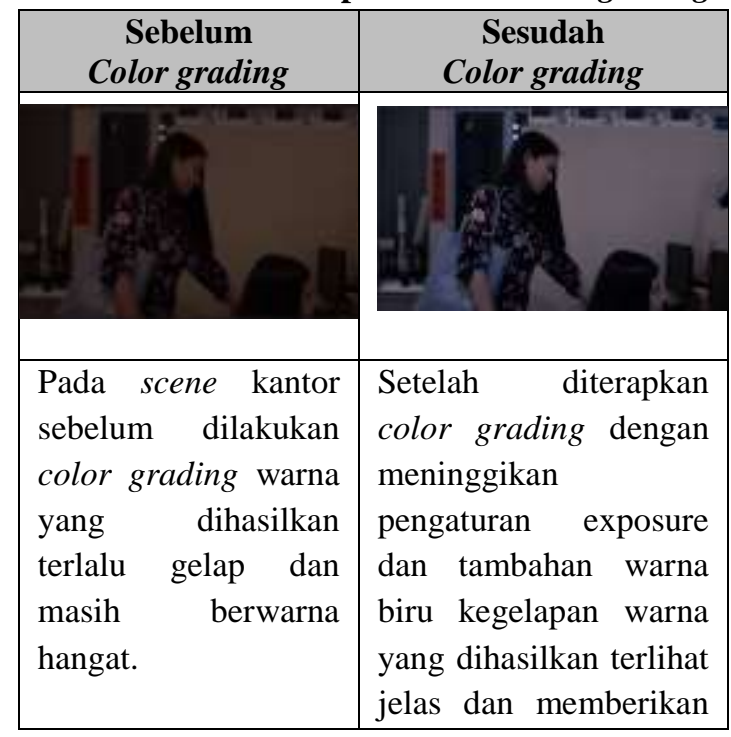




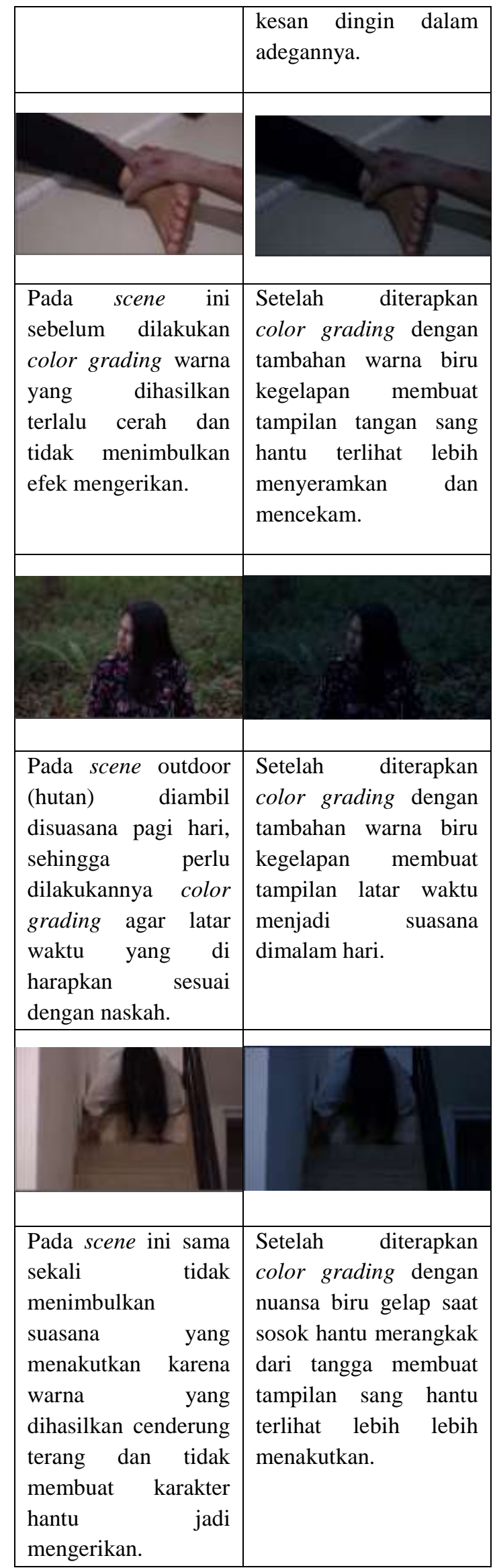




\section{3) Proses Penerapan Musik Scoring}

Setelah proses pemberian warna pada film selesai, proses selanjutnya yaitu memilih musik latar (musik scoring) yang sesuai dengan tema. Format musik yang digunakan ialah mp3. Proses musik scoring dilakukan selama kurang lebih 2 minggu. Musik - musik yang digunakan adalah musik Free Lisence yang bersumber dari Audio Library Youtube. Karena kurangnya sumber daya baik dari segi alat, biaya, maupun orang yang ahli dalam pembuatan musik, penulis tidak memproduksi musik scoring dengan sendirinya. Proses musik scoring dilakukan pada aplikasi adobe premiere pro cc 2017 dengan melakukan spotting atau penempatan musik pada tiap potongan-potongan adegan dalam film dan mengatur tinggi rendahnya volume musik. Keseimbangan antara sound effect, suara narasi dan musik pengiring harus dibuat sedemikian rupa sehingga tidak saling mengganggu dan terdengar jelas. Suara yang menciptakan rasa takut selalu bermain dalam kontras yang mengejutkan sehingga dapat menarik penonton ke dalam suasana, dan saat itulah otak akan diisi oleh perasaan takut. Maka dari itu pentingnya memainkan volume dalam menciptakan musik pada film horor [4]. Proses musik scoring disajikan pada Gambar 6.
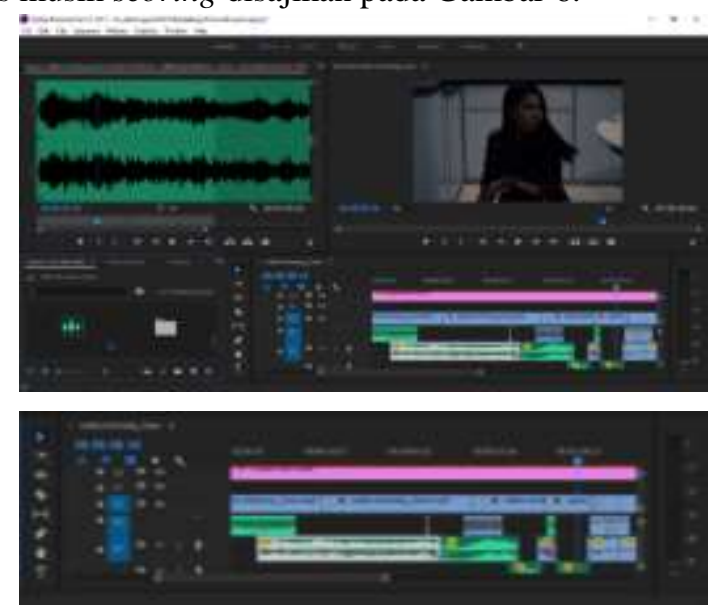

Gambar 6. Proses Musik Scoring

\section{4) Hasil Implementasis Musik Scoring}

Hasil implementasi dari proses Musik scoring dapat dilihat pada tabel 3.

Tabel 3. Hasil Implementasi Musik Scoring

\begin{tabular}{|c|c|c|}
\hline Durasi & Judul & Keterangan \\
\hline $\begin{array}{c}00: 00: 10: 00 \\
- \\
00: 02: 00: 00\end{array}$ & $\begin{array}{l}\text { Controlled } \\
\text { Chaos.mp3 }\end{array}$ & $\begin{array}{l}\text { Menggunakan } \\
\text { musik dengan } \\
\text { nada piano } \\
\text { rendah dengan } \\
\text { tujuan } \\
\text { memberikan } \\
\text { efek tenang } \\
\text { pada awal } \\
\text { film. }\end{array}$ \\
\hline $\begin{array}{c}00: 03: 30: 03 \\
- \\
00: 04: 02: 16\end{array}$ & $\begin{array}{c}\text { Gathering } \\
\text { Darkness.mp3 }\end{array}$ & $\begin{array}{l}\text { Menggunakan } \\
\text { musik dengan } \\
\text { instrumen bass } \\
\text { secara tiba-tiba } \\
\text { dengan tujuan } \\
\text { memberikan } \\
\text { efek penasaran } \\
\text { karena adanya } \\
\text { tambahan } \\
\text { suara tepuk } \\
\text { tangan. }\end{array}$ \\
\hline
\end{tabular}




\begin{tabular}{|c|c|c|}
\hline $\begin{array}{c}00: 05: 20: 08 \\
- \\
00: 05: 33: 22\end{array}$ & $\begin{array}{c}\text { King's } \\
\text { Men.mp3 }\end{array}$ & $\begin{array}{l}\text { Menggunakan } \\
\text { musik dengan } \\
\text { instrumen bass } \\
\text { dengan } \\
\text { volume tinggi } \\
\text { yang } \\
\text { tujuannya } \\
\text { memberikan } \\
\text { efek kaget dan } \\
\text { penasaran } \\
\text { sekaligus takut } \\
\text { karena pintu } \\
\text { kamar terbuka } \\
\text { dengan } \\
\text { sendirinya. }\end{array}$ \\
\hline $\begin{array}{c}00: 05: 46: 17 \\
- \\
00: 05: 49: 00\end{array}$ & Anxiety.mp3 & $\begin{array}{l}\text { Menggunakan } \\
\text { musik dengan } \\
\text { nada tinggi } \\
\text { yang bertujuan } \\
\text { untuk } \\
\text { membangun } \\
\text { suasana } \\
\text { mengejutkan } \\
\text { karena } \\
\text { munculnya } \\
\text { sekilas sosok } \\
\text { hantu secara } \\
\text { tiba-tiba }\end{array}$ \\
\hline $\begin{array}{c}00: 06: 56: 12 \\
- \\
00: 07: 19: 03\end{array}$ & & $\begin{array}{l}\text { Menggunakan } \\
\text { jenis musik } \\
\text { dengan tempo } \\
\text { nada cepat } \\
\text { yang } \\
\text { tujuannya } \\
\text { memberikan } \\
\text { efek khawatir } \\
\text { sekaligus } \\
\text { menyeramkan } \\
\text { karena adanya } \\
\text { adegan dikejar } \\
\text { sosok hantu. }\end{array}$ \\
\hline $\begin{array}{c}00: 07: 33: 10 \\
- \\
00: 07: 35: 02\end{array}$ & $\begin{array}{c}\text { Bump In The } \\
\text { Night.mp3 }\end{array}$ & $\begin{array}{l}\text { Menggunakan } \\
\text { jenis musik } \\
\text { dengan tangga } \\
\text { nada naik } \\
\text { turun dan } \\
\text { diiringi } \\
\text { degupan } \\
\text { jantung sang } \\
\text { tokoh utama, } \\
\text { bertujuan } \\
\text { untuk } \\
\text { memberikan } \\
\text { perasaan yang } \\
\text { sama ketika } \\
\text { audience } \\
\text { menonton } \\
\text { pada scene ini. }\end{array}$ \\
\hline
\end{tabular}




\begin{tabular}{|c|c|c|}
\hline $\begin{array}{c}00: 07: 38: 07 \\
- \\
00: 08: 06: 12\end{array}$ & $\begin{array}{c}\text { King's } \\
\text { Men.mp3 }\end{array}$ & $\begin{array}{l}\text { Menggunakan } \\
\text { musik dengan } \\
\text { diawali suara } \\
\text { gong dan } \\
\text { dilanjutkan } \\
\text { instrument } \\
\text { bass dengan } \\
\text { nada perlahan } \\
\text { rendah yang } \\
\text { bertujuan } \\
\text { membangun } \\
\text { mood } \\
\text { penasaran } \\
\text { karena adanya } \\
\text { perpindahan } \\
\text { scene antara } \\
\text { gambar gelap } \\
\text { ke scene hutan. }\end{array}$ \\
\hline $\begin{array}{c}\text { 00:08:11:04 } \\
- \\
00: 08: 40: 12\end{array}$ & $\begin{array}{c}\text { Awkward } \\
\text { Meeting.mp3 }\end{array}$ & $\begin{array}{l}\text { Menggunakan } \\
\text { instrument } \\
\text { nada piano } \\
\text { rendah untuk } \\
\text { menampilkan } \\
\text { credit title dari } \\
\text { film. }\end{array}$ \\
\hline
\end{tabular}

Setelah video melewati proses color grading dan musik scoring selanjutnya melakukan tahap rendering dan mastering, kemudian dilakukan tahap pengujian dengan cara melakukan pengujian alpha yang dilakukan oleh para ahli perfilman sebagai tahapan evaluasi pemeriksaan pewarnaan/color grading dan musik scoring/musik pengiring dalam pembuatan film ini, dengan menampilkan hasil implementasi color grading dan musik scoring yang telah diterapkan, serta dilakukannya pengujian beta terhadap film horor "Waktu Terlarang" kepada 30 responden yang menyukai film horor. Berikut pengujian yang dilakukan :

a) Pengujian alpha

Pada tahap pengujian alpha dilakukan pengecekan terhadap film yang telah dibuat oleh penulis untuk ahli di bidang perfilman yang memahami color grading dan musik scoring, dikarenakan untuk mengetahui kekurangan yang dimiliki pada film dan juga saran yang harus di perbaiki kedepannya dalam proses pembuatan film horor "Waktu Terlarang". Pengujian dilakukan dengan mengisi kuesioner yang terdapat pertanyaan-pertanyaan yang telah di sesuaikan dengan film yang telah di buat. Adapun orang-orang yang terlibat dalam Ahli perfilman yaitu Jupriyat Moko, S.T selaku Chief Executive Officer (CEO) dan Head Film Division di Zettamind Studios, Daniel Yusuf selaku Chief Financial Officer (CFO) di Zettamind Studios, dan Trio Novelis selaku DOP dan Editor film Ramlie Oii Ramlie. Setelah pengisian kuesioner dilakukan penghitungan persentase dari masing-masing indikator kuesioner. Adapun perhitungan persentase rata-rata setiap indikator yang disajikan dalam tabel 4.

Tabel 4. Hasil Presentase Indikator Kuesioner Ahli Perfilman

\begin{tabular}{|c|l|l|l|}
\hline No & Indikator & Index & $\begin{array}{l}\text { Presen } \\
\text {-tase }\end{array}$ \\
\hline 1. & $\begin{array}{l}\text { Hue (Tingkat } \\
\text { Warna) }\end{array}$ & $\mathbf{2 5 / 3 0 \times 1 0 0}$ & $\mathbf{8 3 \%}$ \\
\hline 2. & $\begin{array}{l}\text { Saturation } \\
\text { (Kepekatan } \\
\text { Warna) }\end{array}$ & $\mathbf{2 5 / 3 0 \times 1 0 0}$ & $\mathbf{8 3 \%}$ \\
\hline
\end{tabular}




\begin{tabular}{|l|l|l|l|}
\hline 3. & $\begin{array}{l}\text { Luminance } \\
\text { (Kecerahan } \\
\text { Warna) }\end{array}$ & $\mathbf{2 3 / 3 0} \times 100$ & $\mathbf{7 6 \%}$ \\
\hline 4. & Tema Musik & $\mathbf{2 4 / 3 0} \times 100$ & $\mathbf{8 0 \%}$ \\
\hline 5. & $\begin{array}{l}\text { Penempatan } \\
\text { Musik }\end{array}$ & $\mathbf{2 2 / 3 0 \times 1 0 0}$ & $\mathbf{7 3 \%}$ \\
\hline 6. & $\begin{array}{l}\text { Kesinambungan } \\
\text { Musik }\end{array}$ & $\mathbf{2 4 / 3 0} \times 100$ & $\mathbf{8 0 \%}$ \\
\hline \multicolumn{2}{|l|}{ Jumlah presentase } & $\mathbf{4 7 5 \%}$ \\
\hline \multicolumn{2}{|l|}{ Rata-rata keseluruhan presentase } & $\mathbf{7 9 \%}$ \\
\hline
\end{tabular}

Setelah mengetahui hasil persentase keseluruhan indikator yang didapatkan sebesar 79\% dengan interval index mencapai kategori Setuju, dan disimpulkan film horor "Waktu Terlarang" layak untuk dipublikasikan. Sehingga menurut pendapat para ahli, peranan color grading sangat penting untuk meningkatkan nilai estetika dan kualitas pada film. Begitu pula peranan musik scoring mampu menutup beberapa kekurangan dari departemen visual, bahkan memberikan kekuatan suasana dari suatu adegan misalnya suasana menjadi mencekam pada film horor. Namun perlu adanya sedikit saran terhadap produk film yang harus diperbaiki. Adapun mengenai saran-saran yang diberikan oleh para ahli disajikan pada Tabel 5.

Tabel 5. Saran Ahli Perfilman

\begin{tabular}{|l|l|l|}
\hline No & Nama & Saran \\
\hline 1. & $\begin{array}{l}\text { Jupriyat } \\
\text { Moko }\end{array}$ & $\begin{array}{l}\text { Pencahayaan yang kurang } \\
\text { konsisten pada scene teras } \\
\text { rumah }\end{array}$ \\
\hline 2. & $\begin{array}{l}\text { Daniel } \\
\text { Yusuf }\end{array}$ & $\begin{array}{l}\text { Pada scene hantu dibelakang } \\
\text { tokoh utama, perjelas suara } \\
\text { nafas tokoh utama. }\end{array}$ \\
\hline 3. & Trio Novelis & $\begin{array}{l}\text { Hilangkan musik pada saat } \\
\text { adegan panci jatuh. Agar } \\
\text { lebih terdengar suara tepuk } \\
\text { tangan. }\end{array}$ \\
\hline
\end{tabular}

Setelah penulis merevisi atau memperbaiki saran sesuai dengan saran yang diberikan oleh para ahli mengenai film horor "Waktu Terlarang" ini maka selanjutnya penulis dapat melanjutkan ke tahap pengujian selanjutnya yaitu tahap pengujian beta.

\section{b) Pengujian beta}

Pada analisis terhadap pengujian beta akan dilakukan uji- $\mathrm{t}$ berpasangan. Pengujian dilakukan dengan menyebarkan kuesioner melalui media online yaitu website google forms. Pengujian beta yang telah dilakukan menghasilkan sebanyak 30 data hasil pengisian kuesioner.

Analisis pertama yang dilakukan yaitu melakukan uji-T sampel berpasangan terhadap aspek color grading. Data dianalisis dengan uji-t menggunakan software SPSS. Hasil analisis dapat dilihat pada gambar 7. 


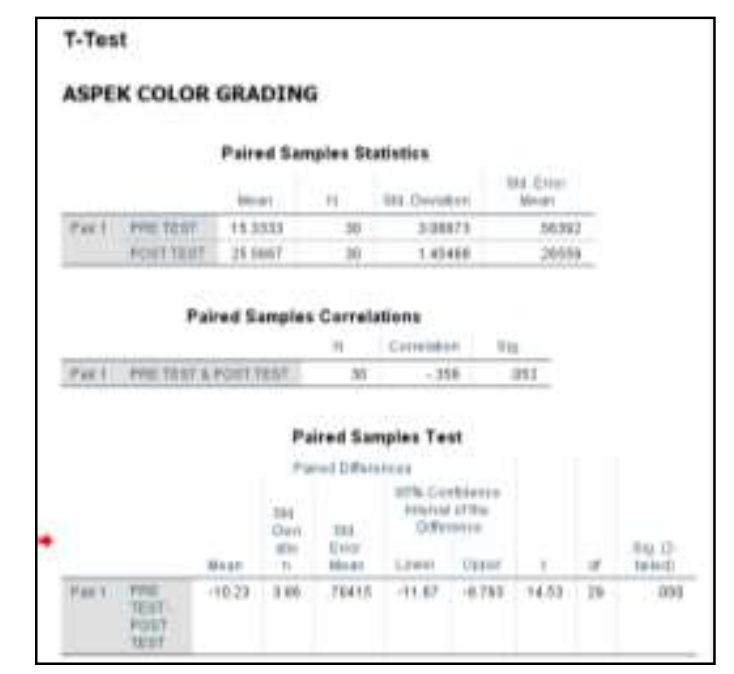

Gambar 7. Hasil analisis Uji T Aspek Color grading

Berdasarkan gambar di atas, diperoleh $\mathrm{t}$ hitung adalah 14,53. Sedangkan $\mathrm{t}$ tabel dengan taraf signifikan $5 \%$ dan $\mathrm{db}=29(30-1)$ adalah 2,045. Hal ini berarti bahwa t hitung > t tabel $(14,53>2,045)$, ataupun diketahui bahwa nilai sig. sebesar $0,00<0,05$ maka Ho ditolak dan H1 diterima, dan dinyatakan bahwa terdapat perbedaan yang signifikan antara film sebelum diterapkan color grading dengan film sesudah diterapkan color grading.

Analisis selanjutnya yaitu melakukan uji-T dengan sampel berpasangan terhadap aspek musik scoring. Data dianalisis dengan uji-t menggunakan software SPSS. Hasil analisis dapat dilihat pada gambar 8.

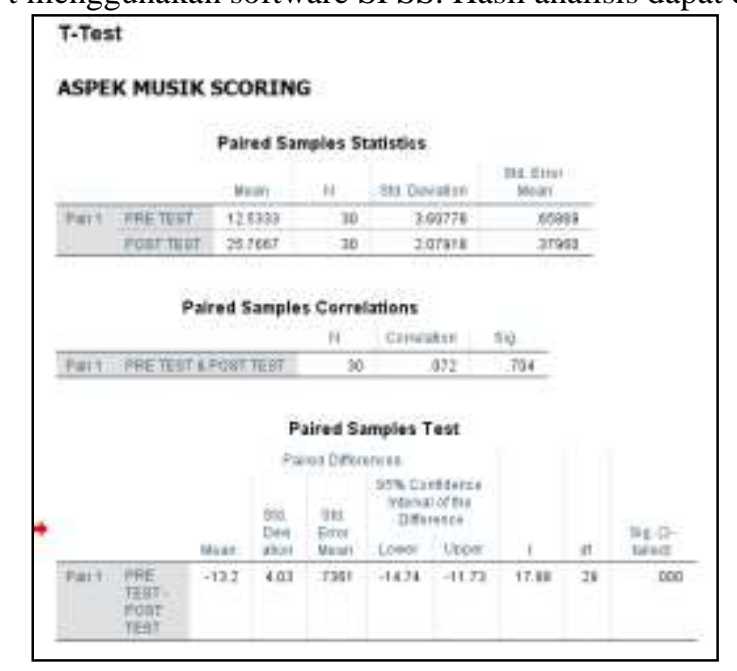

Gambar 8. Hasil analisis Uji T Aspek Musik Scoring

Berdasarkan gambar 7 di atas, diperoleh t hitung adalah 17,98. Sedangkan $t$ tabel dengan taraf signifikan $5 \%$ dan $\mathrm{db}=29(30-1)$ adalah 2,045. Hal ini berarti bahwa t hitung $>\mathrm{t}$ tabel (17,98 $>2,045)$, ataupun diketahui bahwa nilai sig. sebesar $0,00<0,05$ maka Ho ditolak dan H1 diterima, dan dinyatakan bahwa terdapat perbedaan yang signifikan antara film sebelum diterapkan musik scoring dengan film sesudah diterapkan musik scoring.

\section{KESIMPULAN}

Berdasarkan penelitian yang dilakukan, maka dirumuskan kesimpulan sebagai berikut:

1. Menerapkan teknik color grading dan musik scoring dalam pembuatan film horor "Waktu Terlarang" berdurasi 8 menit 50 detik dengan format mp4.

2. Berdasarkan hasil pengujian oleh ahli perfilman, hasil persentase keseluruhan indikator yang didapatkan sebesar 79\% dengan interval index mencapai kategori Setuju, dan disimpulkan film horor "Waktu Terlarang" layak untuk dipublikasikan. Sehingga menurut pendapat para ahli, peranan color grading pada tahap paska produksi sangat penting untuk meningkatkan nilai estetika dan kualitas pada film. 
Begitu pula peranan musik scoring mampu menutup beberapa kekurangan dari departemen visual, bahkan memberikan kekuatan suasana dari suatu adegan misalnya suasana menjadi mencekam pada film horor.

3. Berdasarkan hasil analisis pengujian beta pada aspek color grading dinyatakan bahwa penerapan color grading berpengaruh terhadap tahapan paska produksi film horor "Waktu Terlarang". Hal ini menunjukkan bahwa penilaian dari responden rata-rata menyatakan setuju jika terjadi adanya pengaruh kenaikan kualitas pewarnaan antara sebelum dan sesudah dilakukannya color grading.

4. Berdasarkan hasil analisis pengujian beta pada aspek musik scoring dinyatakan bahwa penerapan musik scoring berpengaruh terhadap tahapan paska produksi film horor "Waktu Terlarang". Sehingga pengaruh musik film horor "Waktu Terlarang" bagi responden dapat membangun mood dan menciptakan ketegangan dalam film.

\section{UCAPAN TERIMAKASIH}

Peneliti mengucapkan terima kasih kepada semua yang telah memberikan dukungan dan bimbingan selama penelitian sehingga ini berjalan dengan baik, yaitu:

1. Kepada pihak Zettamind Studio terkhusus Bpk. Jupriyat Moko yang telah membimbing dan bekerja sama hingga penelitian ini selesai.

2. Kepada Bpk. Fandy Neta sebagai pembimbing di Politeknik Negeri Batam yang membimbing hingga laporan penelitian ini selesai.

3. Kepada para ahli media perfilman yang telah menilai hasil editing film horor "Waktu Terlarang" dan memberikan saran sehingga film yang dihasilkan menjadi lebih baik.

\section{REFERENSI}

[1] Darmawan, A. 2017. Pembuatan Film Pendek Action "Wild" Dengan Penerapan Teknik Color Correction dan Color grading Pada Lumetriadobe Premiere Pro Cc. Fakultas Ilmu Komputer, Universitas Amikom, Yogyakarta.

[2] D. Kho, 2017, Pengertian Skala Likert dan Menggunakannya, http://teknikelektronika.com/pengertianskala-likert-likert-scale-menggunakan-skala-likert/, diakses pada tanggal 29 November 2019, Pukul 13.54 WIB.

[3] Gunapriatna, A., 2017, Hantu Film Indonesia Pindah Menjadi Hantu Urban, Jurnal Imaji, 1, 9, 1-6.

[4] Haryanto, A., 2016, Horornya Musik dalam Film Horor. https://tirto.id/horornya-musik-dalam-film-hororb1NG. Diakses 11 Maret 2020. Pukul 15.42 WIB.

[5] Herlambang, H. 2020. Bagaimana Film Horor Membangun Rasa Takut Penontonnya. https://www.kincir.com/movie/cinema/bagaimana-film-horor-bangun-rasa-takut. Diakses pada 12 Agustus pukul 14.00 WIB.

[6] Kurniawan, D. 2008. Uji T Berpasangan (Paired T-Test), Vienna (AT) Foundation for Statistical Computing.

[7] Montolalu, C.E.J.C, \& Langi, Y.A.R. (2018). Pengaruh Pelatihan Dasar Komputer dan Teknologi Informasi bagi Guru-Guru dengan Uji-T Berpasangan (Paired Sample T-Test). Jurnal Matematika dan Aplikasi deCartesiaN, 7, 2302-4224.

[8] Nur, M.F, \& Nasrullah, M.F.A. (2019). Implementation and analysis of Color grading techniques In documentary filmmaking "Batam Vietnam Village". Journal of Applied Multimedia and Networking, 3, 2548-6853.

[9] Pratista, H. 2008. Memahami Film. Homerian Pustaka. Yogyakarta.

[10] Randawati, L.R., Slamet, L. dan Ilham, M. 2018, Konstruksi Visual Scene Tembang Durma Kuntilanak Dalam Film Kuntilanak Melalui Teknik Montage, Program Studi Televisi dan Film, Fakultas Ilmu Budaya, Universitas Jember. Jember.

[11] Sugiyono. 2010. Metode penelitian Kuantitatif Kualitatif dan R\&D. Bandung: Alfabeta Susan, Hayward. 1996. Key Concept in Cinema Studies.Gramedia. 